Cezary Kulesza

\title{
ROZSTRZYGNIĘCIE SPRAWY KARNEJ W ROZSĄDNYM CZASIE JAKO GWARANCJA RZETELNEGO PROCESU (UWAGI NA TLE PRAWNOPORÓWNAWCZYM)
}

\section{Miejsce zasady rozstrzygnięcia sprawy w rozsądnym czasie w modelu rzetelnego procesu}

Zasada rzetelnego procesu jest obecnie uważana za naczelną zasadę procesu karnego i oznacza prawo do sprawiedliwego i jawnego rozpoznania sprawy w rozsądnym terminie przez właściwy, niezależny, niezawisły i bezstronny sąd ustanowiony ustawą, przy rozstrzyganiu o zasadności każdego oskarżenia w wytoczonej sprawie karnej, przy zachowaniu podstawowych gwarancji praw oskarżonego i pokrzywdzonego. Pojęcie rzetelnego procesu może być także rozumiane jako wzorzec ukształtowania całego postępowania, jako synteza obowiązujących zasad określających metody postępowania. W tym kontekście P. Wiliński wskazuje, że koncepcja rzetelnego procesu może być traktowana jako sposób określenia modelu procesu karnego. Chodzi tu o model postępowania w znaczeniu „gwarancyjnym”, tj. wskazującym, jaka jest jego metoda (osiągnięcie rozstrzygnięcia przy zapewnieniu ochrony praw wszystkich uczestników postępowania) bądź jakie wartości ma realizować i jakie warunki spełniać, dążąc do osiągnięcia stanu prawdy materialnej. ${ }^{1}$ Traktując zasadę rzetelnego procesu jako naczelną zasadę procesową, wypada wskazać, że jest to zasada skodyfikowana zarówno $\mathrm{w}$ aktach prawa międzynarodowego: ${ }^{2} \mathrm{w}$ art. 6 ust. 1 Europejskiej Konwencji o Ochronie Praw Człowieka i Podstawowych Wolności z 1950 r. i art. 14 Międzynarodowego Paktu Praw Obywatelskich i Politycz-

\footnotetext{
1 P. Wiliński, Pojęcie rzetelnego procesu, (w:) A. Błachnio-Parzych, J. Kosonoga, H. Kuczyńska, C. Nowak, P. Wiliński, Rzetelny proces karny w orzecznictwie sądów polskich i międzynarodowych, red. P. Wiliński, Warszawa 2009 r., s. 26 i podana tam literatura oraz E. Skrętowicz, Z problematyki rzetelnego procesu karnego, (w:) Rzetelny proces karny. Księga jubileuszowa Profesor Zofii Świdy red. J. Skorupka, Warszawa 2009, s. 21-27.

2 Zob. także M. Płachta, Rzetelny proces karny w Unii Europejskiej, (w:) Rzetelny proces karny. Księga..., op. cit., s. $28-44$.
} 
nych z 19 grudnia 1966 r. (Dz.U. z 1997 r. Nr 38, poz. 167), jak i w prawie polskim, przede wszystkim w art. 45 ust. 1 Konstytucji RP.

Wskazując na miejsce zasady rozstrzygnięcia sprawy karnej w rozsądnym czasie (reasonable time) w modelu rzetelnego procesu, wypada wskazać na niejednoznaczne rozumienie tej zasady. Przede wszystkim nie należy jej utożsamiać z zasadą (bądź regułą) szybkości postępowania w kontekście chociażby stwierdzenia T. Kotarbińskiego, że szybkość jest wrogiem dobrej roboty. Na gruncie procesu karnego skomplikowany charakter „kompleksu” rzetelnego procesu nakazuje niekiedy przeciwstawiać szybkość postępowania gwarancjom praw oskarżonego w procesie, a w szczególności prawa do obrony. Z zasady rzetelnego procesu wynika więc konieczność zachowania pewnego standardu minimalnego prawa do obrony (materialnej i formalnej) w oparciu o art. 6 ust. 3 Europejskiej Konwencji Praw Człowieka (KE) i art. 14 ust. 3 Międzynarodowego Paktu Praw Obywatelskich i Politycznych (MPPOP) :

Na standard ten składa się: ${ }^{3}$

- prawo do otrzymania informacji (w języku zrozumiałym) o istocie i przyczynie skierowanego oskarżenia (art. 6 ust. 3 lit. a KE i art. 14 ust. 3 lit. a MPPOiP),

- prawo do posiadania odpowiedniego czasu i sposobności do przygotowania się do obrony oraz do porozumiewania się z obrońcą (art. 6 ust. 3 lit. b KE i art. 14 ust. 3 lit. b MPPOiP),

- prawo do przesłuchania lub spowodowania przesłuchania świadków oskarżenia oraz żądania obecności i przesłuchania świadków obrony na tych samych warunkach, co świadków oskarżenia (art. 6 ust. 3 lit. d KE i art. 14 ust. 3 lit. e MPPOiP),

- prawo do korzystania z bezpłatnej pomocy tłumacza, jeśli oskarżony nie rozumie lub nie mówi językiem używanym w sądzie (art. 6 ust. 3 lit. e KE i art. 14 ust. 3 lit. f MPPOiP),

- prawo do nieprzymuszania do zeznawania przeciwko sobie lub do przyznania się do winy (art. 14 ust. 3 lit. g MPPOiP).

Tak więc wypada zauważyć przynajmniej możliwość sprzeczności pomiędzy szybkim ,załatwieniem” sprawy karnej a prawem oskarżonego do posiadania odpowiedniego czasu i sposobności do przygotowania się do obrony oraz do porozumiewania się z obrońcą.

P. Hofmański, E. Sadzik, K. Zgryzek, Kodeks postępowania karnego. T. I. Komentarz do art. 1-296, wyd. 2, Warszawa 2004, s. 50-51; Z. Gostyński, S. Zabłocki, (w:) Bratoszewski J., Gardocki L., Gostyński Z., Przyjemski S.M., Stefański R.A., Zabłocki S., Kodeks postępowania karnego. Komentarz, T. I, Warszawa 2003, s. 218. 
Art. 6 ust.1 EKPC odnosi się do rozpoznania w rozsądnym czasie zarówno spraw karnych, jak i cywilnych. Jego celem jest ochrona stron postępowania przed nadmiernymi, nieuzasadnionymi opóźnieniami, co ma znaczenie przede wszystkim w sprawach karnych, Zgodnie z orzecznictwem ETPC właśnie w procesie karnym należy unikać sytuacji, w której oskarżony pozostawałby w niepewności co do swojego losu. Jednakże Trybunał nie określa żadnego ogólnego terminu trwania postępowania, a nakazuje każdorazowo badać okoliczności konkretnej sprawy. Za punkt początkowy postępowania karnego orzecznictwo strasburskie przyjmuje „dzień postawienia określonej osoby w stan oskarżenia”, traktowanego jako „oficjalne powiadomienie osoby przez odpowiedni organ o zarzucie popełnienia przez nią przestępstwa"(a więc może być to moment wcześniejszy niż skierowanie aktu oskarżenia do sądu). Dlatego też ETPC w swoich orzeczeniach za początek okresu „postawienia w stan oskarżenia” uznawał moment aresztowania, oficjalnego powiadamiania osoby, że będzie ściganie karne, a także wszczęcie postępowania przygotowawczego. Natomiast momentem końcowym procesu karnego jest dzień prawomocnego zakończenia postępowania w sprawie. ${ }^{4}$ Wśród czynników, jakie ETPC bierze pod uwagę przy ocenie, czy dany okres postępowania był rozsądny, można wymienić stopień złożoności danej sprawy, zachowanie oskarżonego, postawę odpowiednich władz sądowych, a także znaczenie sprawy dla oskarżonego. ${ }^{5}$

Ten ostatni czynnik dotyczy najczęściej sytuacji, gdy oskarżony w trakcie procesu karnego jest pozbawiony wolności, gdyż wówczas w kontekście art. 5 ust. 3 Konwencji ETPC wielokrotnie wskazywał, że to sądy krajowe są odpowiedzialne za organizację przebiegu procesu karnego i to na nich spoczywa ciężar podjęcia decyzji, czy przedłużane pozbawienie wolności skazanego jest konieczne dla zabezpieczenia prawidłowego przebiegu procesu, zaś jeśli areszt nie służy już temu celowi, wówczas należy go uchylić. W przeciwnym bowiem razie Trybunał uznaje nieuzasadnioną przewlekłość postępowania, zwracając zresztą uwagę na prawidłowe rozpoznawania (w warunkach rzeczywistej kontradyktoryjności posiedzeń) wniosków i zażaleń w przedmiocie tymczasowego aresztowania. ${ }^{6}$

Należy jednak stwierdzić, że od pewnego czasu ETPC stwierdza niemożność rozpoznania skargi indywidualnej dotyczącej przewlekłości postępowania sądowego ze względu na niewyczerpanie drogi krajowej, o której mowa w art. 35 EKPC. W przypadku Polski Trybunał początkowo oddalał na tej podstawie skargi, wska-

Zob. orzecznictwo podane przez C. Nowak, Prawo do rzetelnego procesu w świetle EKPC i orzecznictwa ETPC, (w:) Rzetelny proces karny w orzecznictwie sądów polskich i międzynarodowych, red. P. Wiliński, Warszawa 2009, s. $114-115$.

$5 \quad$ Ibidem, s. 115-117.

6 Zob. np. C. Kulesza, Effective Defence in the Pre-trial Detention Proceedings: (Remarks in the Light of the Judgment of Strasburg Tribunal of January 15, 2008, Łaszkiewicz v. Poland), (w:) Current Problems of the Penal Law and the Criminology: Aktuelle Probleme des Strafrechts und der Kriminologie, ed. by Emil W. Pływaczewski, Białystok 2009, s. 283-290 I podane tam orzecznictwo ETPC. 
zując na niewyczerpanie drogi przewidzianej w ustawie z dnia 17 czerwca 2004 r. o skardze na naruszenie prawa strony do rozpoznania sprawy w postępowaniu sądowym bez nieuzasadnionej zwłoki (Dz.U. Nr 179 poz. 163). Jednakże w ostatnich orzeczeniach w sprawach polskich ETPC wskazał na niedoskonałości tej ustawy, która nie regulowała kwestii przewlekłości postępowania przygotowawczego. ${ }^{7}$ $\mathrm{W}$ rezultacie ustawa ta została znowelizowana na mocy ustawy $\mathrm{z}$ dnia 20 lutego 2009 r. (Dz.U. Nr 61 poz. 498), rozszerzając jej zakres na postępowanie przygotowawcze z dniem 1 maja $2009 \mathrm{r}$.

Jeśli chodzi o statystykę, to zgodnie z raportami ETPC w okresie 1998-2008 Trybunał rozpoznał ogółem 3403 skargi (w 2009 r. - 449 skarg) na przewlekłość postępowania na ogólną liczbę rozpoznanych 9.736 skarg (w 2009 r. - 1625 skarg), z czego z Polski rozpoznano 308 skarg (w 2009 r. -50 skarg) ${ }^{8}$.

Warto również zauważyć, że standardy art. 6 ust. 1 EKPC i art. 14 ust. 3 lit c MPPOiP dotyczące rozpoznania sprawy w rozsądnym czasie są odnoszone także do międzynarodowych trybunałów karnych. Zgodnie bowiem z art. 20 ust.4 lit c Statutu Międzynarodowego Trybunału Karnego ds. Rwandy i art. 21 ust. 4 lit. c Statutu Międzynarodowego Trybunału Karnego ds. byłej Jugosławii oskarżony ma prawo do rozpoznania sprawy bez zbędnej zwłoki. Wskutek obserwowanej przewlekłości postępowania przed tymi trybunałami wprowadzono kolejne rozwiązania procesowe umożliwiające m.in. ograniczenie ilości przesłuchiwanych świadków, skrócenie długości przesłuchań, ustanawianie terminów zawitych do zgłaszania wniosków formalnych, rozstrzygania kwestii faktycznych i prawnych przed faktycznym wszczęcia postępowania, a także zwiększenia ilości sędziów. ${ }^{9}$

Należy postawić pytanie, czy zasada rozstrzygnięcia sprawy karnej w rozsądnym czasie ma służyć przede wszystkim usunięciu stanu niepewności oskarżonego pozostającego pod zarzutem popełnienia przestępstwa czy też głównie usprawnieniu i zwiększeniu efektywności systemu wymiaru sprawiedliwości w sprawach karnych?

\section{Efektywność systemu wymiaru sprawiedliwości i środki służące jej zwiększeniu w krajach europejskich}

Wypada wskazać, że w związku z kryzysem wymiaru sprawiedliwości w Europie na szczególnym znaczeniu zyskały próby zwiększenia skuteczności syste-

7 C. Nowak, Prawo do rzetelnego procesu w świetle EKPC..., op. cit., s. 117-118 i podane tam orzecznictwo.

8 European Court of Human Rights, Annual Report 2008, Strasburg 2009, s. 138-139; Annual Report (provisional version), Strasbourg, January 2010, s. 141-142.

9 Zob. P. Wiliński, H. Kuczyńska, Rzetelny proces karny w orzecznictwie międzynarodowych trybunałów karnych, (w:) Rzetelny proces karny w orzecznictwie..., op. cit., s. 193-195. 
mów procesowych, co przejawiało się w uchwaleniu już w latach 80. i 90. ubiegłego stulecia szeregu rekomendacji Komitetu Ministrów Rady Europy, których przedmiotem było poszukiwanie metod przyspieszenia i uproszczenia procedury karnej, a także usprawnienia pracy policji, prokuratorów i sądów. Do najważniejszych należała rekomendacja nr R(87)18 z 18 września 1987 r. w sprawie symplifikacji procedury karnej oraz nr R(96)8 z 5 września 1996 r. w sprawie polityki karnej w Europie $\mathrm{w}$ okresie przemian. ${ }^{10}$

Generalnie można dokonać rozróżnienia pomiędzy efektywnością systemu wymiaru sprawiedliwości ujmowanej w znaczeniu węższym (sensu stricto) i w znaczeniu szerokim (sensu largo). Ujęcie pierwsze pozwala przyjąć, że wymiar sprawiedliwości funkcjonuje efektywnie, jeśli działa sprawnie, czyli szybko i oszczędzając na kosztach. Natomiast efektywność wymiaru sprawiedliwości sensu largo obejmuje nie tylko aspekt sprawności, lecz także pełną realizację wszystkich stawianych przed nim celów i konsekwentną realizację podstawowych zasad procesowych i ich gwarancji. Jednakże pewne wewnętrzne sprzeczności pomiędzy celami procesu karnego czynią w mniejszym lub większym stopniu niemożliwą ich realizację przez same organy wymiaru sprawiedliwości i wspomagające je organy ścigania.

W dużej mierze przyśpieszenie procesu zależy nie tylko (i nie przede wszystkim) od kolejnych nowelizacji prawa, lecz od zmian technicznych, organizacyjnych i kadrowych, które nie wpływają na prawa oskarżonego (w tym prawo do obrony). W literaturze przedmiotu wskazuje się tutaj na postępującą technologizację procesu, wzrost znaczenia biegłych i specjalistów, konieczność szkolenia przyszłych sędziów, prokuratorów ${ }^{11}$ (a także adwokatów), problem odpowiedniego dofinansowania sądownictwa, wzmocnienie roli organów procesowych (przy zwiększeniu roli aktywności obrońców w procesie), ${ }^{12}$ odpowiednią organizację pracy organów procesowych oraz zapewnienie odpowiednich warunków infrastrukturalnych działania (w szczególności sędziów) i nadzór służbowy oraz procesowy nad ich działalnością. $^{13}$

10 Na temat tych aktów i ich implementacji w państwach europejskich por. S. Waltoś, Pragmatyzm i antypragmatyzm w procedurze karnej, (w:) Nowe prawo karne procesowe. Księga ku czci W. Daszkiewicza, T. Nowak (red.), Poznań 1999, s. 57-58.

11 Por. S. Waltoś, Wizja procesu karnego XXI wieku, (w:) Postępowanie karne w XXI wieku (materiały z konferencji), P. Kruszyński (red.), Warszawa 2002, s. 30-33; A. Lach, Wykorzystanie technologii informatycznych w postępowaniu karnym po nowelizacji kodeksu postępowania karnego z 10 stycznia 2003 r., (w:) Problemy znowelizowanej procedury karnej, op. cit., s. 159-168.

12 A. Murzynowski; Refleksje na temat kształtu procedury karnej w XXI wieku, (w:) Postępowanie karne w XXI wieku, op. cit., s. 37-51.

13 M.A. Eder-Rieder, (w:) Zagubiona szybkość procesu. Jak ją przywrócić ? S. Waltoś, J. Czapska - red, Warszawa 2005, s. 89-90; P. Hofmański, D. Szumiło-Kulczycka, S. Waltoś, Przewlekłość procesu karnego w Polsce i środki jej zwalczania, (w:) Zagubiona szybkośc procesu, op. cit., s. 54-56. 
Z kolei do regulacji prawnych służących usprawnieniu postępowania karnego, a niezagrażających (przynajmniej w znaczącym zakresie) efektywności sprawowania funkcji obrońcy w ustawodawstwach różnych krajów można zaliczyć: ${ }^{14}$

- wstępne filtrowanie spraw celem ochrony przed obciążeniem sprawami, w których nie ma realnych perspektyw wykrycia przestępstwa lub jego sprawcy;

- przyspieszanie biegu procesu przy pomocy terminów czynności procesowych;

- przepisy służące zapewnieniu koncentracji i ciągłości rozprawy;

- odformalizowanie czynności procesowych niemających istotnego znaczenia dla sprawowania obrony;

- zapobieganie wędrówce sprawy (przed jej merytorycznym zakończeniem) między sądami bądź innymi organami procesowymi oraz powstrzymywanie procesu przed cofaniem sprawy;

- dyscyplinowanie uczestników procesu;

- eliminowanie wątków cywilistycznych z procesu karnego.

Na przykład w literaturze angielskiej wskazuje się na różne aspekty efektywności systemu wymiaru sprawiedliwości rozumianej w znaczeniu szerokim, w kontekście praw człowieka. ${ }^{15}$ Niektóre z nich działają na korzyść praw człowieka, a w szczególności oskarżonego. W doktrynie procesu angielskiego za oczywisty przykład takiego aspektu uważa się właśnie położenie nacisku na szybki proces, którego gwarancje mają swoje korzenie jeszcze w Magna Charta i Habeas Corpus Act z 1679 r. ${ }^{16}$ Z kolei inne aspekty szybkości postępowania są neutralne wobec praw człowieka, jak na przykład efektywne zarządzanie napływem spraw sądowych czy prawidłowe utrwalanie czynności sądowych.

Generalnie prawo Anglii i Walii nie przewiduje ograniczeń czasowych pomiędzy wniesieniem oskarżenia i rozpoczęciem rozprawy sądowej. Jednakże dla spraw rozpoznawanych w trybie uproszczonym ustanowiono limit 56 dni od momentu pierwszego przesłuchania przed sądem pokoju (magistrates' court) do rozprawy, zaś w sprawach prowadzonych w trybie zwykłym (wymagających aktu oskar-

14 P. Hofmański, D. Szumiło-Kulczycka, S. Waltoś, tamże, s. 34-50; 24; D. Dölling, Ch. Laue, K.H. Gössel, (w:) Zagubiona szybkość..., op. cit., s. 112-113.

15 Por. L.H. Leigh, Fair Trial and Efficient Justice System. Some Observations on the English Experience (w:) Human Rights and the Rule of Law. Proceedings of the 2nd International Symposium "Europe Beyond the Union", Frankfurt (Oder), 27-30 March 2002, R.A. Alleweldt, P. Dimitrova, J. Drohla, T. Milej (red.), Kraków 2004, s. 325326.

Pomijając rozwiązania procesu USA, pod wpływem tradycji brytyjskiej podobne instytucje wprowadziła także Kanada, por. K. Roach, M.L. Friendland, The Right to Fair Trial in Canada, (w:) The Right to a Fair Trial, D. Weisbrodt, R. Wolfrum (red.), Berlin 1998, s. 4-12. 
żenia) limit taki wynosi 70 dni od momentu przesłuchania przed tymże sądem do dnia wstępnej sądowej kontroli oskarżenia przez Sąd Królewski (Crown Court sąd wyższej instancji) i 112 dni od tej ostatniej daty do otwarcia rozprawy głównej przed Sądem Królewskim. ${ }^{17}$

Jednakże, jak podkreśla się w literaturze przedmiotu, pewne dążenia do zwiększenia efektywności procesu angielskiego, np. drakońskie uproszczenia procedury zagrażają takim wartościom, jak rozkład ciężaru dowodu czy prawo do spokojnego korzystania z własności. Jak wskazuje L.H. Leigh, angielski system wymiaru sprawiedliwości nie wypracował perfekcyjnej syntezy tych konkurujących wartości. ${ }^{18}$

Wskazać należy również na liberalne prawo angielskie dotyczące środków zapobiegawczych (Bail Act 1976, znowelizowany w 1993 r.), zezwalające większości oskarżonym odpowiadać z reguły z wolnej stopy (przy pewnych ograniczeniach w przypadku oskarżonych popełniających poważne przestępstwa wymagające aktu oskarżenia, jeśli popełnili je w okresie stosowania kaucji - bail), ustanawiające prymat kaucji nad aresztem tymczasowym. ${ }^{19}$

Podobne regulacje służące zwiększeniu szybkości procesu bez ograniczania praw oskarżonego, a nawet służące ich wzmocnieniu (w szczególności, jeśli pozostaje on w areszcie) obowiązują w Danii, ${ }^{20}$ Norwegii, ${ }^{21}$ Hiszpanii (tu wynikają przede wszystkim z Konstytucji z 1978 r. . $^{22}$ czy we Włoszech. ${ }^{23}$ Oczywiście, w tych krajach Europy Zachodniej zasada rozstrzygania spraw karnych w rozsądnym czasie (reasonable time) bądź też szybkiego procesu (speed trial) jest niewątpliwie konsekwencją implementacji w ich ustawodawstwach art. 6 Europejskiej konwencji o ochronie praw człowieka, statuującego zasadę rzetelnego procesu (fair trial). ${ }^{24}$

Idea rozstrzygnięcia sprawy w rozsądnym terminie przyświecała niewątpliwie ustanowieniu w poszczególnych państwach maksymalnych okresów tymczasowego aresztowania, które z jednej strony służą przyśpieszeniu procesu, z drugiej zaś ustanawiają czasowe limity ograniczania pełnej swobody kontaktów oskarżonego z obrońcą. Konieczność zachowania takich terminów należy rozpatrywać łącznie z regulacjami przewidującymi obowiązkowy udział obrońcy w sprawach oskarżo-

17 R. Dickson, The Right to a Fair Trial in England \& Wales, (w:) The Right to a Fair Trial, D. Weisbrodt, R. Wolfrum (red.), Berlin 1998, s. 501-502.

Ibidem, s. 326.

Por.: R. Dickson: The Right to a Fair Trial in England \& Wales, op. cit., s. 493-495.

S. Garde, The Right to Fair Trial in the Kingdom of Denmark, (w:) The Right to Fair Trial, op. cit., s. 538-552.

S.E. Jebens, The Right to a Fair Trial in Norway, (w:) The Right to Fair Trial, op. cit., s. 589-592.

J. Calatayud, The Right to a Fair Trial in Spain, (w:) The Right..., op. cit., s. 603-607.

F. Tribulato, The Right to a Judgement within a „Reasonable Time” in Italy, (w:) Human Rights and the Rule of Law. Proceedings of the 2nd International Symposium "Europe Beyond the Union”, Frankfurt (Oder), 27-30 March 2002, R.A. Alleweldt, P. Dimitrova, J. Drohla, T. Milej (red.), Kraków 2004, s. 487-502.

Por. np. L.H. Leigh, The Right, (w:) Fair Trial, op. cit., s. 645-668; S. Stavros, The Guarantees for Accused Person Under Article 6 of the European Convention on Human Rights, Dordrecht-Boston-London 1993, s. 208-213 i podane tam orzecznictwo. 
nych pozbawionych wolności. Przykładowo w literaturze niemieckiej i austriackiej wskazuje się wyniki badań, z których wynika, że wczesne angażowanie się obrońców w postępowanie przygotowawcze pozwala na uniknięcie tymczasowego aresztowania podejrzanych bądź skrócenie okresu aresztu i jednoczesne przyśpieszenie procesu. ${ }^{25}$ Należy wiązać również z tą instytucją określanie przez ustawodawcę krótkich terminów rozpoznawania przez sądy środków zaskarżenia decyzji o zastosowaniu bądź przedłużeniu tymczasowego aresztowania (por. art. 5 ust. 4 EKPC).

Ponadto należy wskazać na terminy określające moment wszczęcia postępowania sądowego w przypadku oskarżonych tymczasowo aresztowanych. Poza przytoczonymi wcześniej regulacjami angielskimi można tu wymienić chociażby ustawodawstwo japońskie, które przewiduje, że podejrzany musi zostać zwolniony $\mathrm{z}$ aresztu, jeśli w ciągu 20 dni od jego zastosowania nie zostanie wniesiony akt oskarżenia ( $\$ 208$ japońskiego kpk.). Jednakże w przypadku ciężkich przestępstw po wniesieniu aktu oskarżenia nie istnieje żadne definitywne ograniczenie czasowe stosowania aresztu ( $\$ 60$ ust. 3 japońskiego kpk.).Ponadto przyspieszeniu postępowania karnego w Japonii służą spotkania przed pierwszą rozprawą obrońcy i prokuratora celem uzgodnienia, jakie punkty sporne będą rozpoznawane przed sądem. Obydwie strony mają zadbać o to, aby świadkowie, których chcą powołać, stawili się na pierwszej rozprawie. ${ }^{26}$

\section{Porozumienia procesowe jako metoda akceleracji postępowania karnego (uwagi prawnoporównawcze)}

W europejskiej literaturze procesu karnego wskazuje się, że wspólne interesy efektywnej obrony i sprawnego, czyli szybkiego wymiaru sprawiedliwości mogą doprowadzić do współpracy obrony, oskarżenia i sądu przez zawieranie formalnych (uregulowanych ustawą) bądź nieformalnych porozumień procesowych, służących konsensualnemu zakończeniu procesu i w rezultacie jego przyśpieszeniu, przy poszanowaniu gwarancji prawa do obrony. ${ }^{27}$ Porozumienia takie nie budzą zastrzeżeń

D. Burhoff, Verteidigungsmöglichkeiten im Rahmen der besonderen Haftprüfung durch das OLG — oder: Vermeidung von weiteren Untersuchungshaft durch Verteidigermitwirkung, (w:) Sicherheit durch Strafe? Öffentlicher Strafanspruch zwischen Legalitätsprinzip und Opferinteresse. 26. Strafverteidigertag Mainz, 8.-10. März 2002, Berlin 2002, s. 131-156; U. Busse, S. Hohman, Verkürzung und Vermeidung von Untersuchungshaft durch frühzeitige Strafverteidigung (w:) Sicherheit durch Strafe?, op. cit., s. 157-176; R. Soyer, Vermeidung von Untersuchungshaft durch frühzeitige Verteidigermitwirkung in Österreich, (w:) Sicherheit durch Strafe?, op. cit., s. 177194.

26 M. Ida, (w:) Zagubiona szybkość..., op. cit., s. 96-97.

27 Por. np. J. Peters, B. Aubusson de Cavarlay, C. Levis, P. Sobota, Negotiated Case- ending Settlements: Ways of Speeding up the (Court) Process, „European Journal on Criminal Policy \& Research” 2008, vol.140-154; S. Ufer, F. Ufer, „Die Verständigung“ im Strafverfahren, (w:) Grundlagen der Strafverteidigung, U. Ziegert - red., Stuttgart 2000, s. 45-52; C. Kulesza, K. Boratyńska: Usprawnianie postępowania karnego w Niemczech i Polsce, Prok. i Pr. 2004, nr 4, s. 20-21, 35-36 oraz podana tam literatura; Ch. Bertel, Die Verteidigung im österreichischen Strafverfahren, w: Strafverteidigung - Realität und Vision. I Österreichisches Strafverteidigerlnnentag, Wien 21/22. März 2003, Wien 2003, s. 14; M.A. Eder-Rieder, op. cit., s.17. 
w krajach, gdzie system wymiaru sprawiedliwości oparty jest na zasadzie oportunizmu ścigania (czego klasycznym przykładem jest Anglia), natomiast wątpliwości może budzić ich zgodność z zasadą legalizmu ścigania. Jednakże nawet w Niemczech nieformalne porozumienia procesowe (Absprachen) zostały zaakceptowane przez orzecznictwo Niemieckiego Sądu Konstytucyjnego (BVerfG). Jak wskazuje się $\mathrm{w}$ niemieckiej literaturze przedmiotu, aby pogodzić cele przyśpieszenia procesu przez konsensualne formy zakończenia postępowania karnego z ochroną gwarancji praw oskarżonego, ustawą zmieniającą niemiecki kpk. (StPO) z dniem 1 sierpnia 2009 r. dokonano formalizacji porozumień procesowych na rozprawie głównej (Verständigungen). ${ }^{28}$

Podstawową funkcją porozumień procesowych jest swoista akceleracja postępowania sądowego przez uproszczenie, za zgodą stron, wydania wyroku sądowego i przez to skrócenie całego postępowania. W rezultacie można tu mówić, jak się wskazuje w literaturze zachodniej, o przyśpieszonym wydaniu decyzji kończącej sprawę (fast-tracked case-ending decision), nazywanej ,wynegocjowanym porozumieniem kończącym sprawę" (negotiated case-ending settlements), posiadającym następujące cechy: ${ }^{29}$

1) Decyzja sądu jest oparta na umowie między stronami.

2) Postępowanie kończy się rzeczywistym skazaniem sprawcy.

3) Prawną konsekwencją skazania jest prawdziwe, lecz złagodzone ukaranie.

Przykładem sformalizowanych konsensualnych form zakończenia postępowania karnego jest wprowadzenie do rosyjskiej procedury karnej przyśpieszonego trybu postępowania umożliwiającego w sprawach o przestępstwo zagrożone karą pozbawienia wolności nieprzekraczającą 10 lat skazanie oskarżonego bez przeprowadzania postępowania dowodowego na rozprawie. W przeciwieństwie do polskiej instytucji z art. 387 kpk. sąd nie ocenia dowodów zebranych w sprawie karnej, może natomiast badać okoliczności rzucające światło na osobowość oskarżonego oraz świadczące o stopniu jego zawinienia. Skazanie wymaga wniosku oskarżonego oraz zgody oskarżyciela publicznego, prywatnego bądź pokrzywdzonego. Sąd może skazać oskarżonego na karę nieprzekraczającą 2/3 górnej granicy ustawowego zagrożenia za dane przestępstwo. Jak wskazuje się w literaturze rosyjskiej, taki skrócony tryb rozprawy niewątpliwie przyśpiesza proces, ale stosunek do tej instytucji, zarówno wśród teoretyków, jak i praktyków jest ambiwalentny. ${ }^{30}$ Ponieważ, jak wynika $\mathrm{z}$ niedemokratycznych tradycji rosyjskiego procesu karnego, podstawę obaw

\footnotetext{
28 Zob monografię T. Viering, Absprachen als Verfahrensökonomische Lösung des Schuldnachweisproblems im Strafverfahren, Frankfurt am Main 2009, s. 219-248 i podane tam orzecznictwo.

29 J. Peters, B. Aubusson de Cavarlay, C. Levis, P. Sobota, Negotiated Case-ending Settlements: Ways of Speeding up the (Court) Process, „European Journal on Criminal Policy \& Research” 2008, vol.14, s. 146.

30 I.L. Landau, (w:) Zagubiona szybkość..., op. cit., s. 116-117.
} 
stanowi zagrożenie gwarancji praw oskarżonego, istotną rolę w ich zapewnieniu powinien stanowić udział obrońcy.

Spośród krajów Europy zachodniej opartych o zasadę legalizmu ścigania wypada wskazać na proces włoski charakteryzujący się znaczną przewlekłością postępowania. $\left.{ }^{31}\right){ }^{32}$ Przyczyn tego zjawiska upatruje się w doktrynie włoskiej w złej organizacji sądów, przyzwyczajeniach sędziów do dochodzenia prawdy z urzędu, co powoduje w praktyce odejście od idei kontradyktoryjności (ściśle związanej z regułą fair trial) na rzecz tradycyjnego modelu inkwizycyjnego. ${ }^{33}$ Zjawisku temu mają przeciwdziałać skrócone formy postępowania, oparte na porozumieniu stron procesowych. Wypada tu wskazać na uprawnienie sędziego ds. wstępnej kontroli oskarżenia (giudice dell'udienza preliminare - GUP), podobnie jak sąd orzekający (trybunale) sprawuje kontrolę nad stosowaniem uproszczonej procedury skazania guidizio abbreviato (art. $438 \mathrm{CPP}$ ), której celem jest uniknięcie rozprawy głównej przez umożliwienie wydania orzeczenia na etapie poprzedzającym rozprawę główną. Procedura może być wszczynana na wniosek oskarżonego albo przed przesłuchaniem wstępnym (iudenzia preliminare), albo w trakcie takiego posiedzenia. W jej pierwotnej wersji prokurator posiadał prawo veta i mógł nalegać na przeprowadzenie rozprawy na zasadach ogólnych. Jednakże w celu upowszechnienia stosowania tej instytucji prawo nr 479 z 1999 r. usunęło wymóg uzyskania zgody prokuratora. W przypadku skazania kara orzekana przez sędziego, przy wzięciu pod uwagę szczególnych okoliczności sprawy, była zmniejszana o 1/3.

Kolejną procedurą umożliwiającą eliminację rozprawy głównej w procesie włoskim jest instytucja orzeknięcia kary na wniosek stron procesowych (applicazione della pena su richiesta delle parti zwana także pattagiamento), określona w art. 444 CPP.

Kara orzeczona na wniosek stron - prokuratora lub oskarżonego, za zgodą drugiej strony bądź ich wspólne żądanie, jest redukowana maksymalnie do 1/3 ustawowego zagrożenia i nie może przekraczać 2 lat. Wniosek taki może być złożony sędziemu w trakcie postępowania przygotowawczego, w ramach posiedzenia przed rozprawą, aż do momentu jej wszczęcia. Przy uwzględnieniu wniosku przez sąd orzeczona może zostać również kara grzywny, a strony mogą także wnosić o za-

31 Jak wynika z raportu Prokuratora Generalnego urzędującego przy Sądzie Najwyższym Włoch za 2003 r. typowa sprawa spoczywa w urzędzie prokuratorskim przez 381 dni. Po wniesieniu aktu oskarżenia posiedzenie GUP w przedmiocie kontroli oskarżenia odbywa się po upływie kolejnych 324 dni. Rozprawa przed sądem powszechnym I instancji (tribunale) trwa 341 dni, a 398 dni przed sądem przysięgłych (Corte d'assises) bądź sądem powszechnym zajmującym się bardzo poważnymi przestępstwami. Rozpatrzenie apelacji zajmuje przeciętnie do 343 dni, a jeszcze dłużej, jeśli sprawa z sądu apelacyjnego trafia do Sądu Najwyższego (Corte di cassazione) G. Illuminati, The Frustrated Turn to Adversarial Procedure in Italy, Turn to Adversial Procedure in Italy (Italian Criminal Procedure Code of 1988), „Washington University Global Studies Review” 2005, vol. 4, s. 580.

33 E. Grande, Italian criminal Justice: Borrowing and Resistance, „American Journal of Comparative Law” 2000, vol. 48 , s. $249-251$. 
wieszenie wykonania kary. Uzgodnienie między oskarżycielem a obrońcą dotyczy przede wszystkim kary, jaka ma zostać wymierzona oskarżonemu i może nastąpić już w postępowaniu przygotowawczym. Ten musi zbadać, czy strony dobrowolnie zawarły porozumienie i jeśli akceptuje ich propozycję, wydaje wyrok. Jeżeli prokurator odmówił wyrażenia zgody, musi podać przyczyny swojej decyzji. Sędzia musi zbadać, czy nie ma podstaw do uniewinnienia i czy wniosek stron pozostaje w zgodzie z prawem oraz czy proponowana kara jest proporcjonalna do zarzucanych czynów. Sąd rozpoznaje wniosek stron na posiedzeniu ${ }^{34}$

Instytucja porozumień procesowych jest przedmiotem ciągłej dyskusji we włoskiej doktrynie prawa i procesu karnego. Większość przedstawicieli prawa karnego jest zdeklarowanymi przeciwnikami bądź przynajmniej sceptycznie nastawionymi obserwatorami wszelkich porozumień procesowych, jako zagrażającym bądź naruszającym cele wymiaru sprawiedliwości. Natomiast procesualiści karni skłaniają się do poglądu, że zarówno regulacje prawne, jak i praktyka porozumień procesowych nie budzi zastrzeżeń zarówno ze względu na podstawowe prawa procesowe (takie jak prawo do milczenia, domniemanie niewinności i prawo do rzetelnego procesu), podstawowe zasady procesowe (zasada niezawisłości sędziowskiej czy zasada legalizmu), jak i uzasadniają je względy pragmatyczne (odciążenie wymiaru sprawiedliwości). ${ }^{35}$

Odnosząc się generalnie do porozumień procesowych kończących postępowanie w krajach europejskich, należy wskazać, że ich stosowanie dotyczy z reguły występków (Francja), bądź też kodeksy przewidują górne granice ustawowego zagrożenia ograniczające katalog spraw, gdzie takie postępowanie może mieć miejsce. Tak więc maksymalna kara pozbawienia wolności możliwa do orzeczenia w takich trybach wynosi: we Francji 5 lat, na Węgrzech 8 lat, w Chorwacji 10 lat (w trybie przyspieszonym) i 5 lat (skazanie przez sędziego śledczego). W krajach tych przewiduje się ograniczenia wymiaru kary, jaką sąd może wymierzyć w trybie porozumienia procesowego, która nie może przekraczać: 1 roku pozbawienia wolności we Francji, 2 lat w Hiszpanii, 3 lat na Węgrzech i 3 roku w Chorwacji (skazanie przez sędziego śledczego). We wszystkich krajach wymierzona kara powinna być łagodniejsza niż w przypadku przeprowadzenia pełnej rozprawy. Przykładowo w Hiszpanii prawo przewiduje, że taka kara powinna być złagodzona o 1/3 (wzorem sądów angielskich), w Chorwacji maksymalna kara wynosi 1/3 maksymalnego zagrożenia ustawowego zagrożenia ${ }^{36}$.

34 A. Perrodet, The Italian System, (w:) European Criminal Procedures, M. Delmas-Marty, J.R.Spencer - red., wyd. 3, Cambridge 2008 s. 372-373 i podana tam literatura.

35 R. Orlandi, Landesbericht Italien, (w:) Strafverteidigung vor neuen Herausforderungen, T. Weigend, S. Walther B. Gruenewald- red., Berlin 2008, s. 249 i podana tam literatura..

36 J. Peters, B. Aubusson de Cavarlay, C. Levis, P. Sobota, Negotiated Case- ending Settlements, op. cit., s. 156157. 
W krajach europejskich do skazania w trybie porozumień procesowych wymagana jest zgoda oskarżonego, zaś w Hiszpanii, Francji i Węgrzech oraz w trybie przyspieszonym w Chorwacji konieczne jest przyznanie się oskarżonego do winy. W krajach tych sąd na rozprawie bądź posiedzeniu aktywnie bada przesłanki dopuszczalności porozumienia procesowego i samego skazania w tym trybie. ${ }^{37}$

Podany wyżej przykład procesu włoskiego jest o tyle istotny, gdyż na nim zasadniczo wzorowano instytucje konsensualnego zakończenia postępowania wprowadzone do art. 335 i 387 polskiego kpk. z 1997 r. Również w literaturze polskiej wskazuje się, że podstawową funkcją skazania bez rozprawy i dobrowolnego poddania się odpowiedzialności karnej jest uproszczenie trybu wydawania wyroku skazującego i skrócenie postępowania w sytuacji, gdy na takie procesowanie strony procesowe wyrażają zgodę. To właśnie uproszczenie i przyspieszenie postępowania było celem, jaki chciał osiągnąć ustawodawca. ${ }^{38}$ Warto zauważyć, że wskutek reformy kpk. dokonanej ustawą z 10 stycznia 2003 r. (Dz.U. Nr 17 poz. 155) rozszerzono zakres stosowania tych instytucji. Ponadto nowe brzmienie art. 343 par. 1 i 2. kpk. pozwala na orzeczenie o odpowiedzialności karnej oskarżonego na odrębnych i znacznie korzystniejszych dla oskarżonego zasadach. W związku z powyższym, w literaturze przedmiotu obecnie zgodnie przyjmuje się, że w par. 1 i 2 art. 343 kpk. ustawodawca zawarł normę materialnoprawną, zaś par. 3-7 tegoż artykułu przewidują procedurę stosowania dopuszczalnych materialnoprawnych ustępstw na rzecz oskarżonego. Paragraf 2 art. 343 kpk. zawiera samodzielną materialnoprawną podstawę nadzwyczajnego złagodzenia kary (pkt 1), warunkowego zawieszenia wykonania kary (pkt 2) oraz ograniczenia skazania do orzeczenia środka karnego ${ }^{39}$. Warto dodać, że z danych statystycznych Ministerstwa Sprawiedliwości wynika, że w trybie konsensualnym skazano w 2007 r. ponad 55\% osób, przeciwko którym wniesiono akt oskarżenia, a łącznie $\mathrm{z}$ wyrokami warunkowo umarzającymi postępowania - łącznie ponad $57 \%$. Jest to oceniane w literaturze jako niepokojące statystycznie, mające wymiar jakościowy odstępstwo od zasady bezpośredniości postępowania dowodowego na rozprawie głównej, w oparciu o kryterium zgody bądź braku sprzeciwu zainteresowanych stron. ${ }^{40}$ Warto też zauważyć, że w obecnym stanie prawnym skazania w powyższych trybach konsensualnych zapadają, podobnie jak w analizowanych europejskich systemach prawnych, na podstawie dowodów policyjnych i prokuratorskich, bez przeprowadzania przez sąd własnego postępowania dowodowego w sprawie. Dlatego też należy dostrzec zagrożenia, jakie rodzą takie tryby dla

$37 \quad$ Ibidem, s. 157.

38 S. Steinborn, Porozumienia w polskim procesie karnym. Skazanie bez rozprawy i dobrowolne poddanie się odpowiedzialności karnej, Kraków 2005, s. 57.

39 P. Hofmański, E. Sadzik, K. Zgryzek, Kodeks postępowania karnego. T. II, Komentarz do artykułów 297-467, Warszawa 2004, s. 293-295

40 Zob. J. Tylman, Uwagi o modelu postępowania przygotowawczego, (w:) Węzłowe problemy procesu karnego P. Hofmański - (red.) Warszawa 2010, s. 97-98. 
zasady prawdy obiektywnej i innych podstawowych zasad procesowych, dostrzegane w polskiej literaturze przedmiotu. ${ }^{41} \mathrm{~W}$ tym kontekście można stwierdzić, że konsensualne sposoby zakończenia postępowania w polskim systemie wymiaru sprawiedliwości odgrywają już znaczącą rolę w przyspieszeniu procesu ${ }^{42}$, a dalsze ich rozszerzania np. na sprawy o zbrodnie mogłoby zagrozić gwarancjom praw oskarżonego bądź pokrzywdzonego.

\section{Uwagi końcowe}

Podsumowując, wypada także zauważyć, że w krajach europejskich przejawem tendencji do ekonomizacji i przyspieszenia procesu jest także odchodzenie od instytucji śledztw sądowych prowadzonych przez sędziego śledczego i położenie nacisku głównie na funkcję gwarancyjną pełnioną przez sędziego ds. śledztwa, który poza stosowaniem środków przymusu utrwala na wniosek stron jedynie najważniejsze dowody, wykorzystywane później bezpośrednio na rozprawie. Takie osłabienie sądowej kontroli postępowania przygotowawczego ma być rekompensowane większym angażowaniem obrońców w proces, co ma równoważyć rosnące uprawnienia prokuratury. $^{43}$

Czas w procedurze karnej jest ważnym, lecz nie najważniejszym determinantem wpływającym na model procesu karnego. Sprawa karna ma być rozstrzygana w rozsądnym terminie, a nie ,tak szybko, jak to możliwe”. W dziedzinie sprawowania wymiaru sprawiedliwości czas nie jest absolutem, lecz pojęciem względnym, podlegającym relatywizacji w odniesieniu do gwarancji sprawiedliwości proceduralnej. Jeśli reguła szybkości postępowania znajdzie się w konflikcie z podstawowymi zasadami procesowymi, takimi jak zasada prawdy materialnej, zasada prawa do obrony, domniemania niewinności czy zasada ochrony praw pokrzywdzonego, zarówno ustawodawca, jak i organ procesowy powinien rozstrzygać taką kolizję na korzyść tych zasad. Dlatego też dalsza ewolucja europejskich modeli procesu karnego nie może podążać dalej w kierunku przyspieszania postępowania karnego kosztem podstawowych gwarancji praw jego uczestników. Wydaje się, że ta metoda ekonomizacji systemów wymiaru sprawiedliwości osiągnęła w Europie (w tym w Polsce) już swoje granice. Dalsze usprawnienie wymiaru sprawiedliwości w Polsce może być osiągane zasadniczo nie w drodze kolejnych nowelizacji prawa, lecz

41 Zob. np. H. Paluszkiewicz, S. Stachowiak, Rozwiązania konsensualne wprowadzone do polskiego procesu karnego a wykrycie prawdy, (w:) Zasada prawdy materialnej. Materiały z konferencji Krasiczyn 15-16 października 2005 r., Z. Sobolewski, G. Artymiak - (red.), kraków 2006, s. 91-110; Z. Świda, W. Jasiński, M. Kuźma, Dyrektywa rozstrzygania sprawy „w rozsądnym terminie” a realizacja zasady prawdy materialnej w polskim procesie karnym, (w:) Zasada prawdy materialnej, ibidem, s. 20-23;

42 Zob. np. monografię Ocena funkcjonowania porozumień procesowych w praktyce wymiaru sprawiedliwości, red. C. Kulesza, Warszawa 2009.

43 Zob. C. Kulesza, Sędzia śledczy a współczesny proces karny (na tle prawnoporównawczym), PiP 2008, nr 7, s. $20-43$ i podana tam literatura. 
przez zmiany techniczne, organizacyjne i kadrowe, które nie wpływają na prawa oskarżonego (w tym prawo do obrony). Jak wskazano w wcześniej, należy dostrzegać postępującą technologizację procesu, wzrost znaczenia biegłych i specjalistów, konieczność szkolenia przyszłych sędziów, prokuratorów i policjantów. Jeśli postawimy na zmiany ustawodawcze, to tylko takie, które zapobiegają nieuzasadnionej przewlekłości procesu, np. służące wstępnemu ,filtrowaniu” spraw, zapobiegające ich ciągłej wędrówce pomiędzy sądami czy wprowadzające sztywne terminy procesowe a przez to służące przestrzeganiu gwarancjom praw uczestników postępowania. W tym kontekście należałoby postulować pod adresem ustawodawcy, aby były to zmiany przemyślane, a to - jak wiadomo - wymaga czasu. 


\title{
DETERMINATION OF CRIMINAL CASE WITHIM REASONABLE TIME AS A GUARANTEE OF A FAIR TRIAL (REMARKS IN COMPARATIVE PERSPECTIVE)
}

\author{
SUMMARY
}

The article centres around the notion of "fair trial": a key element in Article 6 of the European Convention of Human Rights and Article 14 of the UN International Covenant on Civil and Political Rights of 1966 . Those acts proclaim a set of basic rights which all contracting States bind themselves to respect. Article 6 (1) of the Convention gives the defendant the right to have his case heard "within a reasonable time" and many European countries (i.a. Poland) have been condemned at Strasburg for breach of this provision. Key elements relevant to this right are: "reasonable time" guarantees, protection against excessive procedural delays, start and end of "relevant period", particular circumstances of the case, factors taken into account (complexity of case, conduct of applicant and conduct of competent administrative and judicial authorities)..

The Convention and the Strasbourg case law have made contracting States more conscious of the problem of delay, and stimulates its legislators to find different ways to overcame it. In many European countries, much of the reforms of criminal procedure has centred around the need to reduce the use of pre trial detention and shortening the time limits between accusation and trial. The measures which accelerate directly criminal proceedings and reduce backlog of cases in courts are among others: preliminary "filtration" of cases, liquidating civil suits connected with criminal cases, restructuring of administration and "technologisation" of the proceedings

Important issue discussed in this article is a special type of fast- tracked case ending decisions called "negotiated case ending - settlements". Those proceedings (which can be found in six European countries) are based on a kind of agreement between the parties, end with real conviction of the offender and their legal consequence is a true but mitigated punishment. In conclusion, the author pointed out oc- 